Maria Esteban-Rihuete Luis Moreno-Borraz ${ }^{2}$ Diego Rodríguez-Gascón ${ }^{2}$ Julio César García-Herrero ${ }^{3}$ Juan Manuel GarcíaLechuz $^{4}$ Ángel García-Forcada ${ }^{2}$

\section{Clostridioides difficile infection in a long-term convalescence hospital: A real tale of pitfalls and outdated therapy}

\author{
'Facultad de Medicina, Universidad de Zaragoza, Spain \\ ${ }^{2}$ Hospital San Juan de Dios, Zaragoza, Spain \\ ${ }^{3}$ Ayuntamiento de Zaragoza, Servicio de Salud Pública, Spain \\ ${ }^{4}$ Hospital Miguel Servet, Servicio de Microbiología, Zaragoza, Spain
}

Article history

Received: 29 July 2020; Revision Requested: 22 September 2020; Revision Received: 30 September 2020; Accepted: 6 0ctober 2020; Published: 1 December 2020

\section{ABSTRACT}

Objective. The aim of the study was to know the characteristics and risk factors of Clostridioides difficile infection (CDI) in a long-term hospital is key to improve its management.

Material and methods. Retrospective study with 37 patients, along 43 months. We describe demographic variables, clinical data, time to diagnosis, treatment, and evolution.

Results. Analysis of 46 episodes (37 patients, mean age $=82.2$ years). $77.8 \%$ were absolutely dependent, $41.7 \%$ had chronic kidney disease, $64.9 \%$ had received antibiotics in the previous three months, $40.5 \%$ received antibiotics at diagnosis. It was the first episode in 78.4\%, and first recurrence in $21.6 \%$. Therapy was started in the first 24 hours after diagnosis in $89.2 \%$, mostly metronidazole. $83.3 \%$ recovered, 3 patients died from $\mathrm{CDI}$, diagnosis was registered in the discharge report in 91.1\%.

Conclusions. Previous antibiotic therapy, high grade of dependency and renal failure were the main risk factors. There is room for improvement in CDI management at our hospital.

Keywords Clostridium difficile, Clostridioides difficile, nosocomial infection, recurrent infection, management.

\section{Infección por Clostridioides difficile en un hospital de convalecencia: una historia real de trampas y tratamiento anticuado}

\section{RESUMEN}

Objetivo. Conocer las características y factores de riesgo de infección por Clostridioides difficile (ICD) en un hospital de convalecencia es clave para mejorar su manejo.

Material y métodos. Estudio retrospectivo con 37 pacientes, durante 43 meses. Describimos variables demográficas, datos clínicos, tiempo hasta el diagnóstico, el tratamiento y la evolución.

Resultados. Análisis de 46 episodios (37 pacientes, edad media $=82,2$ años). 77,8\% tenían dependencia absoluta, 41,7\% enfermedad renal crónica, 64,9\% habian recibido antibióticos en los 3 meses previos, 40,5\% recibian antibióticos en el momento del diagnóstico. Fue el primer episodio en $78,4 \%$, y la primera recidiva en $21,6 \%$. En el $89,2 \%$ se comenzó tratamiento en las primeras 24 horas tras el diagnóstico, mayoritariamente metronidazol. El 83,3\% se recuperaron. 3 pacientes murieron por ICD. El diagnóstico figuraba en el informe de alta en $91,1 \%$.

Conclusiones. El tratamiento antibiótico previo, un alto grado de dependencia, y el fracaso renal, fueron los factores de riesgo principales. Hay margen de mejora en el manejo de ICD en nuestro hospital.

Palabras clave: Clostridium difficile, Clostridioides difficile, infección nosocomial, infección recurrente, manejo

\footnotetext{
Correspondence: 


\section{INTRODUCTION}

Clostridioides difficile infection (CDI) is the most frequent cause of nosocomial diarrhoea. It is a global health problem, with most cases acquired in hospital but also described in the community. Reported mortality rate ranges between 3-15\%, and recurrence rate, $12-40 \%[1,2]$.

Hospital San Juan de Dios (HSJD) is a long term-acute care hospital with 188 beds, holding units of palliative care, neurorehabilitation, haemodyalisis for chronic patients, convalescence, and an acute geriatric unit. Patients are admitted from acute care hospitals of the region, and directly from nearby centres of primary care, with a catchment area of 500.000 inhabitants. These types of health facilities have their own features and challenges concerning CDI $[3,4]$.

\section{MATERIAL AND METHODS}

We have performed a retrospective study of all CDI cases since 5th May 2016 to 31st December 2019. We used the definitions of nosocomial, community-acquired and recurrent CDI reported in updated guidelines $[5,6]$. In every patient with a clinical picture suggestive of CDI (diarrhoea, abdominal pain, fever), a faecal sample was collected and analysed at the microbiology laboratory of the hospital, using $C$. difficile quik check complete (Techlab ${ }^{\circledR}$ Blacksburg) test. This is a fast membrane enzyme-immunoassay which simultaneously detects the bacterial antigen glutamate dehydrogenase (GDH) and also toxins $A$ and B. Samples which were GDH+/Tox- were sent to the reference hospital (Hospital Miguel Servet) for Polymerase Chain Reaction -PCR- testing (GenXpert ${ }^{\circledR}$ Cepheid), which detects a toxin-producer gen [7]. Data obtained from clinical records were fully anonymised and collected using a specifically designed database. For the statistical study, qualitative variables are presented according to distribution of frequencies, and expressed as number and percentage. Quantitative variables are presented as means, median, mode and standard deviation. We did all statistical analysis using SPSS (IBM SPSS Statistics 25.0 2017). The Ethics Committee of Clinical Research of Aragón (CEICA) approved the study project (ruling 31/01/2020), as did the Ethics Committee of HSJD.

\section{RESULTS}

Patients, risk factors and clinical data. We describe 37 patients diagnosed of CDI during the study period (24 men/13 female), mean age $82.8+/-9.6$ years (56-100). Patient's demographics and clinical data before and on admission appear in Table 1.

CDI diagnosis, treatment and clinical outcome. (Table 2) There were 46 episodes of CDI (29 first episodes and 17 recurrences). In 29 patients (78.4\%) the infection was the 1st episode, and in 8 cases (21.6\%), the debut episode in our hospital was the first recurrence of CDI. 12 patients out of the 37 presented recurrent CDI during their hospital stay: 8, first recur- rence after an initial episode (21.6\%), 8 as second recurrence, and 1 as third recurrence (overall, 17 episodes in 12 patients). Data concerning the characteristics of the infection (clinical data, treatment, evolution) appear in Table 2.

In 15 patients with CKD and age $>65$ years, CDI was qualified as severe, with a high risk of recurrence according to the guidelines.

The anti-CDI therapy of the first episode was metronidazole in 24/29 (82.8\%), vancomycin in 4/29 (13.8\%), and fidaxomicin in one. The first CDI recurrence was treated with metronidazole in 5 cases, and with vancomycin in 3 cases. The second $C D I$ recurrence was treated with metronidazole in 1 case, vancomycin 2 cases, fidaxomicin 1 case. The third recurrence received fidaxomicin.

\section{DISCUSSION}

We describe in this study the characteristics of 37 patients with CDI in a long term-acute care hospital, trying to confirm if the well-known reported risk factors are also present in our patients, and if the diagnostic and therapeutic approaches employed fit with current guidelines. Most studies have been performed in health facilities of very different profile (tertiary hospitals [8,9], multicentric studies [10], or extensive epidemiological studies [2]). After a thorough bibliographical search, we have not found any study performed in a hospital of our profile.

In our series, almost 60\% of patients came from emergency departments of other hospitals, for convalescence and/ or rehabilitation after infections or cerebrovascular disease. As symptoms may be scarce or not reported, and given the high index of dependency in this population, diagnosis may be a difficult challenge. It is also worth mentioning, as it has been reported in other series [10], the association between CDI and chronic renal insufficiency (15 from 36 patients, 41.7\%, had an eGFR $<50 \mathrm{~mL} / \mathrm{min}$ ). All these factors confer to our patients a high degree of frailty and a high risk of CDI recurrence, a finding also previously described $[8,11,12]$. We also found in our patients a wide use of PPIs, drugs that modify the $\mathrm{pH}$ of the bowel and disrupt bowel microbiota, as well as an association of CDI with previous antibiotic use, also described in previous studies $[3,4,8-11]$. It is important to remark that $40.5 \%$ of patients were on antibiotics at the time of diagnosis, and they were withdrawn in only $53.5 \%$ of them, which may indicate a pitfall in the management of CDI in our patients.

Concerning clinical presentation, most (83.8\%) patients did not refer any symptoms or signs. This scarcity of clinical data indicates that CDI is clinically silent in this population, even in severe cases. Though there are no registered data regarding the number of leukocytes, applying the GEIH Score [12] (age, number of diarrhoeal episodes and renal insufficiency), $40.5 \%$ of patients had severe CDI, with a high risk of recurrence.

Regarding the analysis of the episodes, in $78.4 \%$ of cases CDI presented as the first episode. In $21.6 \%$ of cases, the epi- 


\begin{tabular}{|c|c|c|c|}
\hline Table 1 & \multicolumn{3}{|c|}{ Patients' demographics, clinical data before and on admission. } \\
\hline Variable & & Number (n) & Percentage $(\%)$ \\
\hline \multicolumn{4}{|c|}{ Patients' demographics } \\
\hline \multicolumn{4}{|l|}{ Gender } \\
\hline Female & & $24 / 37$ & $64.9 \%$ \\
\hline Male & & $13 / 37$ & $35.1 \%$ \\
\hline Age & & \multicolumn{2}{|c|}{ Mean $\pm S D=82.8 \pm 9.6$} \\
\hline \multicolumn{4}{|l|}{ Origin } \\
\hline \multicolumn{2}{|c|}{ Emergency department } & $22 / 37$ & $59.5 \%$ \\
\hline \multicolumn{2}{|c|}{ Neurology } & $4 / 37$ & $10.8 \%$ \\
\hline \multicolumn{4}{|c|}{ Pre-diagnosis data } \\
\hline \multicolumn{2}{|c|}{ Patients with infections in the previous 3 months } & $24 / 37$ & $64.9 \%$ \\
\hline \multicolumn{2}{|c|}{ Number of infections } & $\mathrm{N}=28$ & \\
\hline \multicolumn{2}{|c|}{ Respiratory infection } & $8 / 28$ & $28.6 \%$ \\
\hline \multicolumn{2}{|l|}{ CDI } & $8 / 28$ & $28.6 \%$ \\
\hline \multicolumn{2}{|c|}{ Urinary tract infection } & $6 / 28$ & $21.4 \%$ \\
\hline \multicolumn{2}{|c|}{ Patients with antibiotics in the previous 3 months } & $24 / 37$ & $64.9 \%$ \\
\hline \multicolumn{2}{|c|}{ Number of antibiotics } & $N=38$ & \\
\hline \multicolumn{2}{|c|}{ Beta-lactams } & $20 / 38$ & $52.6 \%$ \\
\hline \multicolumn{2}{|c|}{ Glucopeptides } & $5 / 38$ & $13.2 \%$ \\
\hline \multicolumn{2}{|c|}{ Macrolides } & $5 / 38$ & $13.2 \%$ \\
\hline \multicolumn{4}{|c|}{ Clinical data on admission } \\
\hline \multicolumn{4}{|c|}{ Diagnosis on admission } \\
\hline \multicolumn{2}{|c|}{ Respiratory infection } & $7 / 37$ & $18.9 \%$ \\
\hline \multicolumn{2}{|c|}{ Unspecified diarrhoea } & $6 / 37$ & $16.2 \%$ \\
\hline \multicolumn{2}{|l|}{ Sepsis } & $5 / 37$ & $13.5 \%$ \\
\hline \multicolumn{2}{|l|}{ Stroke } & $4 / 37$ & $10.8 \%$ \\
\hline \multicolumn{2}{|c|}{ Days of disease that led to admission } & \multicolumn{2}{|c|}{ Mean $\pm S D=17.8 \pm 21.2$} \\
\hline \multicolumn{2}{|c|}{ Patients with antibiotics on admission } & $21 / 37$ & $56.8 \%$ \\
\hline \multicolumn{2}{|c|}{ Number of antibiotics } & $N=23$ & \\
\hline \multicolumn{2}{|c|}{ Beta-lactams } & $16 / 23$ & $69.6 \%$ \\
\hline \multicolumn{2}{|c|}{ Quinolones } & $2 / 23$ & $8.7 \%$ \\
\hline Barthel on ac & & Me: & $=24.4^{*}$ \\
\hline CKD & & $15 / 36^{*}$ & $41.7 \% \%^{*}$ \\
\hline PPls & & $29 / 37$ & $78.4 \%$ \\
\hline
\end{tabular}

$\mathrm{CKD}=$ chronic kidney disease, (estimated Glomerular Filtration Rate $<50 \mathrm{~mL} / \mathrm{min}$ ); PPIs=proton pump inhibitors.

*Data about clinical outcome was missing in one patient.

sode during hospital stay was a recurrence, as the initial episode had happened previously. According to the current definition of recurrence given by IDSA-SHEA [6], it can be said that $32.4 \%$ suffered from recurrent $C D I$, and $67.5 \%(n=25)$, only an initial episode of CDI, without further recurrences during the length of the hospital stay. This recurrence rate is between 20 and $30 \%$ in the study by Lessa et al. [2] and similar in other studies $[8,11]$; it is reported as high as $57.1 \%$ in one of the studies performed in Spain [11].

In most cases, treatment was started within the same day or the following day after reception of the laboratory diagnosis, which can be a good quality indicator. Considering 


\begin{tabular}{|c|c|c|c|}
\hline \multirow{2}{*}{$\begin{array}{l}\text { Table } 2 \\
\\
\text { Variable } \\
\end{array}$} & \multicolumn{3}{|c|}{ Clinical data of CDI, treatment and evolution until discharge. } \\
\hline & & Number (n) & Percentage $(\%)$ \\
\hline \multicolumn{4}{|c|}{ Clinical data of CDI } \\
\hline \multicolumn{4}{|c|}{ Distribution patients-year } \\
\hline 2016 & & $2 / 37$ & $5.4 \%$ \\
\hline 2017 & & $9 / 37$ & $24.3 \%$ \\
\hline 2018 & & $10 / 37$ & $27 \%$ \\
\hline 2019 & & $16 / 37$ & $43.2 \%$ \\
\hline \multicolumn{4}{|l|}{ CDI origin } \\
\hline Nosocom & & $32 / 37$ & $86.5 \%$ \\
\hline Communi & & $5 / 37$ & $13.5 \%$ \\
\hline Patients with & iotics on diagnosis & $15 / 37$ & $40.5 \%$ \\
\hline Number of a & & $N=19$ & \\
\hline Beta-lact & & $11 / 19$ & $57.9 \%$ \\
\hline Cotrimox & & $3 / 19$ & $15.8 \%$ \\
\hline Withdrawal & biotics on diagnosis & $8 / 15$ & $53.3 \%$ \\
\hline \multicolumn{4}{|c|}{ Clinical findings } \\
\hline Haemody & instability & 0 & $0 \%$ \\
\hline Tachycaro & & $1 / 37$ & $2.7 \%$ \\
\hline Nausea/v & & $3 / 37$ & $8.1 \%$ \\
\hline Abdomin & & $6 / 37$ & $16.2 \%$ \\
\hline Fever & & $10 / 37$ & $27 \%$ \\
\hline Diarrhoea & & $35 / 37$ & $94.6 \%$ \\
\hline$>2$ days & & 20/37 & $54.1 \%$ \\
\hline \multicolumn{4}{|c|}{ Initial episode during hospital stay } \\
\hline First episc & & $29 / 37$ & $78.4 \%$ \\
\hline First recu & & $8 / 37$ & $21.6 \%$ \\
\hline Recurrent CL & & $12 / 37$ & $32.4 \%$ \\
\hline \multicolumn{4}{|c|}{ Treatment } \\
\hline Started $\leq 10$ & er diagnosis & $33 / 37$ & $89.2 \%$ \\
\hline \multicolumn{4}{|c|}{ Antimicrobials } \\
\hline \multicolumn{4}{|c|}{ First episode } \\
\hline Metron & & $24 / 29$ & $82.8 \%$ \\
\hline \multicolumn{4}{|c|}{ First recurrence } \\
\hline Metron & & $8 / 12$ & $66.6 \%$ \\
\hline Contact prec & & $26 / 37$ & $70.3 \%$ \\
\hline \multicolumn{4}{|c|}{ Evolution until discharge } \\
\hline Recovery & & $31 / 36^{*}$ & $86.1 \% \%^{*}$ \\
\hline Derivation tc & center & $1 / 37$ & $2.7 \%$ \\
\hline Death attrib & to CDI & $3 / 37$ & $8.11 \%$ \\
\hline Days of hosp & & \multicolumn{2}{|c|}{ Mean $\pm S D=43.6 \pm 30.0$} \\
\hline Days diagnos & harge & \multicolumn{2}{|c|}{ Mean $\pm S D=23.0 \pm 19.2$} \\
\hline Microbiologi & trol & $4 / 37$ & $10.8 \%$ \\
\hline CDI as princi & gnosis in discharge report & $7 / 37$ & $18.9 \%$ \\
\hline CDI specified & charge report & $34 / 37$ & $91.9 \%$ \\
\hline
\end{tabular}

$\mathrm{CDI}=$ Clostridiodes difficile infection; ${ }^{*}$ Data about clinical outcome was missing in one patient. 
therapeutic approach, 78.4\% of individuals with an initial episode were treated with metronidazole, which was the drug of choice until 2017. However, last guidelines [5,6] advise about the use of vancomycin or fidaxomicin as first line in all patients with first episode of CDI [13-15]. So, it could be said that the degree of penetrance of current therapeutic guidelines is poor in our hospital. Recurrent episodes were also treated inadequately, mostly with metronidazole again.

Despite this, $83.8 \%$ of the patients recovered, a similar high rate is reported by Aljafel et al. [9] and others [8] 8.1\% of deaths in our series were attributable to CDI. This figure is similar to the rate reported by Olsen et al. [15] and also by Lessa et al. [2] and it is even higher in other series $[1,8,10]$. It is worthwhile to remember that all publications belong to health facilities with very different characteristics from our hospital. Mean hospital stay of our patients was 43.6 days (standard deviation: 30.1 days), which is longer than the duration reported by other authors $[8,9]$

We acknowledge the limitations of the study: retrospective, with a small sample, and patients who are far from representative of the general population, as are aged (mean age 82 years) and with multiple comorbidities. It means that CDI is bound to be more severe and the risk of recurrences, higher. However, it has also strengths: it can inspire further research about CDI in the hospital, within the frame of a stewardship team and infection control approach. Moreover, it analyses a type of patients which is specific to this profile of hospitals, scarcely represented in current literature.

\section{FUNDING}

None to declare.

\section{CONFLICTS OF INTEREST}

The authors declare that they have no conflict of interest.

\section{BIBLIOGRAFÍA}

1. Leffler DA, Lamont JT. Clostridium difficile infection. N Engl J Med. 2015; 372: 1539-1548. doi: 10.1056/NEJMra1403772.

2. Lessa FC, Mu Y, Bamberg WM, Beldays ZG, Dumyati JK, Dunn JR, et al. Burden of Clostridium difficile infection in the United States. N Engl J Med. 2015; 372:825-834. doi: 10.1056/NEJMoa 1408913.

3. Jump RL, Crnich CJ, Mody L, Bradley SF, Nicolle LE, Yoshikawa $T$. Infectious diseases in older adults of long-term care facilities: update on approach to diagnosis and management. J Am Geriatr Soc. 2018; 66(4):789-803. doi:10.111/jgs.15248.

4. Chopra T, Goldstein EJC. Clostridium difficile infection in longterm care facilities: a call to action for antimicrobial stewardship. CID. 2015:60 (suppl 2): S72-76. doi: 10.1093/cid/civ053.

5. Bouza $E$, Aguado JM, Alcalá L, Almirante $B$, Alonso-Fernández $P$, Borges $\mathrm{M}$, et al. Recommendations for the diagnosis and treatment of Clostridioides difficile infection: An official clinical practice guideline of the Spanish Society of Chemotherapy (SEO), Spanish Society of Internal Medicine (SEMI) and the working group of Postoperative Infection of the Spanish Society of Anesthesia and Reanimation (SEDAR). Rev Esp Chemotherapy 2020; 33(2):151175. doi: 10.37201/req/2065.2020.

6. McDonald LC, Gerding DN, Johnson S, Bakken JS, Carroll KC, Coffin $\mathrm{SE}$, et al. Clinical practice guidelines for Clostridium difficile infection in adults and children: 2017 update by the Infectious Diseases Society of America (IDSA) and Society for Healthcare Epidemiology of America (SHEA). Clin Infect Dis 2018; 66:1-48. doi: 10.1093/cid/ ciy 149.

7. Alcala-Hernandez L, Mena-Ribas A, Niubo-Bosh J, Marin-Arriaza M. Laboratory diagnosis of Clostridium difficile infection. Enferm Infecc Microbiol Clin 2016; 34(9):595-602. doi: 10.1016/j. eimc.2015.09.004.

8. Karaoui WR, Rustom LBO, Bou Daher H, Rimmani HH, Rasheed SS, Matar GM, et al. Incidence, outcome, and risk factors for recurrence of nosocomial Clostridioides difficile infection in adults: A prospective cohort study. J Infect Public Health 2019; pii: S18760341(19)30343-0. doi: 10.1016/j.jiph.2019.11.005.

9. Aljafel NA, Al-Shaikhy $H$, Alnahdi MA, Thabit AK. Incidence of Clostridioides difficile infection at a Saudi Tertiary Academic Medical Center and compliance with IDSA/SHEA, ACG, and ESCMID guidelines for treatment over a 10-year period. J Infect Public Health. 2020. pii: S1876-0341(20)30408-1. doi: 10.1016/j. jiph.2020.03.007.

10. Abou Chakra CN, McGeer A, Labbe AC, Simor AE, Gold WI, Muller MP. Factors associated with complications of Clostridium difficile infection in a multicenter prospective cohort. Clin Infect Dis. 2015; 61(12):1781-1788. doi: 10.1093/cid/civ749

11. Rodriguez-Pardo, D, Almirante, B, Bartolome, RM, et al. Epidemiology of Clostridium difficile infection and risk factors for unfavourable clinical outcomes: results of a hospital-based study in BarceIona, Spain. J Clin Microbiol 2013; 51: 1465-1473. doi: 10.1128/ JCM.03352-12.

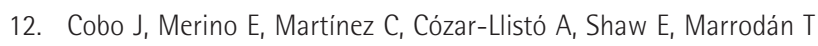
et al. Prediction of recurrent Clostridium difficile infection at the bedside, the GEIH-CDI score. Int J Antimicrob Agents 2018 Mar; 51(3):393-398. doi: 10.1016/j.ijantimicag.2017.09.010.

13. Stevens VW, Nelson RE, Schwab-Daugherty EM, Khader K, Jones $M M$, Brown KA et al. Comparative effectiveness of vancomycin and metronidazole for the prevention of recurrence and death in patients with Clostridium difficile infection. JAMA Intern Med 2017; 177(4):546-553. doi: 10.1001/jamainternmed.2016.9045.

14. Guery B, Manichetti F, Anttila V-J, Adomakoh N, Aguado JM, Bisnauthsing $\mathrm{K}$ et al. Extended-pulsed Fidaxomicin versus vancomycin for Clostridium difficile infection in patients 60 years and older (EXTEND): A randomized, controlled, open-label, phase 3b/4 trial. Lancet Infect Dis 2018 Mar; 18(3):296-307. doi: 10.1016/S14733099(17)30751-X.

15. Olsen MA, Yan Y, Reske KA, Zilberberg MD, Dubberke ER. Recurrent Clostridium difficile infection is associated with increased mortality. Clin Microbiol Infect. 2015; 21:164-70. doi: 10.1016/j. cmi.2014.08.017. 